\title{
New species of Diderma from Vietnam
}

\author{
Novozhilov $\mathrm{YK}^{1}$, Mitchell DW ${ }^{2}$, Okun $\mathrm{MV}^{1,3}$, Shchepin $\mathrm{ON}^{1}$
}

\author{
${ }^{1}$ Komarov Botanical Institute of the Russian Academy of Sciences, Laboratory of Systematics and \\ Geography of Fungi, Prof. Popov Street 2, 197376 St. Petersburg, Russia \\ ${ }^{2}$ Walton Cottage, Upper Hartfield, East Sussex, TN7 4AN, England \\ ${ }^{3}$ CIBIV -Center for Integrative Bioinformatics in Vienna, Max F. Perutz Laboratories (MFPL), University of Vienna, \\ Medical University of Vienna, Campus Vienna Biocenter 5 (VBC5), A-1030, Vienna, Austria
}

Novozhilov YK, Mitchell DW, Okun MV, Shchepin ON 2014 - New species of Diderma from Vietnam. Mycosphere 5(4), 554-564, Doi 10.5943/mycosphere/5/4/8

\begin{abstract}
During intensive studies of the taxonomy and ecology of myxomycetes in Cat Tien National Park (southern Vietnam), two species of Diderma (myxomycetes) were collected during surveys carried out in December 2010 and similar surveys carried out in November 2011 and 2012. These new species, D. cattiense and D. pseudotestaceum, are described and illustrated. D. cattiense resembles $D$. subasteroides in overall shape, colour and size of the sporocarps but has smaller spores and the ornamentation of spores and the capillitium are different. The main morphological differences between $D$. pseudotestaceum and $D$. testaceum lie in shape, colour of sporocarp, columella, spore size and ornamentation. A phylogeny based on the small ribosomal subunit (SSU) and elongation factor 1 alpha (EF1a) genes placed these new species in clades far apart from other species of Diderma.
\end{abstract}

Key words - Amoebozoa - EF1a gene - molecular phylogeny - Myxogastria - plasmodial slime moulds - SSU rRNA gene - Southeast Asia - taxonomy - tropics

\section{Introduction}

Surveys for myxomycetes carried out in lowland dense monsoon semideciduous tropical forests in southern Vietnam in Cat Tien National Park (CTNP) by the first author in December 2010 yielded a series of collections of two species of Diderma that could not be identified in the field. These same species were recorded again in CTNP in January 2011 and December 2012. Later examination of these collections in the laboratory indicated that they did not fit any described species of Diderma.

\section{Materials \& Methods}

\section{Isolates and morphology}

This paper is based on field collections and material obtained from moist chamber cultures of ground litter, aerial litter and bark collected from Cat Tien National Park (CTNP, $11^{\circ} 21^{\prime}-11^{\circ} 48^{\prime} \mathrm{N}$, $107^{\circ} 10^{\prime}-107^{\circ} 34^{\prime}$ E) which is located at the foot of the central Vietnamese highlands in Dong Nai province, about $130 \mathrm{~km}$ northeast of Ho Chi Minh City. All parts of CTNP are hilly, with elevations ranging between 120 and $220 \mathrm{~m}$ a.s.l. (sector Nam Cat Tien) and up to $372 \mathrm{~m}$ a.s.l. (sector Tai Cat Tien) and $659 \mathrm{~m}$ a.s.l. (sector Cat Loc). There are numerous small rocky outcrops 
and lowlands, with the latter usually flooded for several weeks during the rainy season. Lowlands and flatlands are especially characteristic of the eastern part of the region bordering the Dong Nai River. The general study area is characterized by a tropical monsoon climate with two distinct seasons, a rainy season extending from late April to November and a dry season that lasts from December to March. The mean annual temperature is approximately $26^{\circ} \mathrm{C}$, with rather small seasonal fluctuations. The annual rainfall varies from $1800-2500 \mathrm{~mm}$, with the most rain falling during August and September (400-450 mm per month), when much of the park area is inundated with water. In contrast, there is almost no precipitation from January to March (Thinh \& Anichkin 2011). The vegetation of CTPN is very diverse and includes more than 150 tree species, of which Lagerstroemia calyculata (Lythraceae) along with various members of the Dipterocarpaceae, Fabaceae and Datiscaceae often dominate both the upper canopy and subcanopy (Blanc et al. 2000, Kuznetsov \& Kuznetsova 2011, 2013). Most of the upper canopy trees are deciduous and shed their foliage during the dry season. At the end of the dry season (April), a substantial amount of litter (up to $800-1000 \mathrm{~g} \mathrm{~m}^{2}$ ) accumulates on the soil surface. However, with the onset of the rainy season this litter is quickly consumed by termites and other soil invertebrates (Anichkin 2011).

The samples of substrate material used for preparing moist chamber cultures were collected in November-December of 2010-2012. The specimens were air-dried in situ and transported back to the laboratory in sealed paper bags. All the localities were geo-referenced with a portable GPS device (WGS 84 mapping data). In the laboratory, cultures were prepared by placing pieces of paper towel in Petri dishes $(9 \mathrm{~cm}$ diam.) in such a way that most of the bottom surface of each dish (ca $60 \mathrm{~cm}^{2}$ ) was covered. Cultures were flooded with distilled water. After 24 hrs the excess water was poured off. Small amounts of water were added to the cultures at regular intervals to keep the substrates moist. The cultures were maintained for up to three months under diffuse daylight at room temperature $\left(22-23^{\circ} \mathrm{C}\right.$ ) and examined for the presence of myxomycetes on six occasions (days 2-4, $6-8,11-14,20-22,40-44$ and $85-90)$. The $\mathrm{pH}$ of the wet substrate was determined using a Hanna model $9024 \mathrm{pH}$ meter with a flat surface electrode HI-1413 (with measurements taken for three pieces of substrate) during the first examination (days 2-4, $\mathrm{pH} 6.01 \pm 0.24$ for all cultures producing new species, $n=7$ ). Sporocarps of the new species usually appeared within 20-22 days after the moist chamber cultures were started, with the last sporocarps being found at days 40-44. Voucher specimens are deposited in the collection of the first author in the mycological herbarium of the Komarov Botanical Institute, Laboratory of Systematics and Geography of Fungi (LE).

Spore-to-spore cultures were prepared from mature sporocarps grown in moist chamber cultures. Sporocarps were crushed and spores released over agar in sterile plastic Petri dishes with 1.5\% water agar at pH 7.0; to facilitate germination some drops of distilled water were added. Young plasmodia were transferred to agar enriched with sterilized oatmeal (Haskins and Basanta 2008). Cultures were kept at room temperature $\left(20-23^{\circ} \mathrm{C}\right)$ in diffuse light.

Air-dried sporocarps were studied with a Zeiss Axio Imager A1 light microscope with differential interface contrast (DIC), a Stemi 2000 dissection microscope and a JSM-6390 LA scanning electron microscope (SEM) in the Komarov Botanical Institute RAS (St. Petersburg). For microscopy, sporocarps were preserved as permanent slides in polyvinyl lactophenol. The freeware program CombineZ was used to create stacked images under a Stemi 2000 dissection microscope. Microscopic measurements were made with the program Axio Vision 4.8.0.0 (Carl Zeiss Imaging Solutions $\mathrm{GmbH}$, free licence). Spore features (diameter and spore ornamentation) were determined for 10 spores per specimen for each of the specimens examined in detail. Observations of the spore ornamentation by SEM have been made after applying the critical point drying technique (Singer et al. 2005). Specimens for electron microscopy were mounted on copper stubs using double-sided sticky film and sputter-coated with gold. Colour notations in parentheses are from the ISCC-NBS colour-name charts illustrated with centroid colours (Anonymous 2012).

\section{DNA extractions, PCR, DNA sequencing and phylogenetic analyses}

DNA was extracted from sporocarps shock-frozen with liquid nitrogen and crushed using a mortar and pestle. The resulting powder was diluted with PBS, and DNA was extracted with the 
AxyPrep Multisource Genomic DNA Miniprep Kit according to the manufacturer's instructions. For 5 specimens we obtained partial SSU sequences (the first part of the gene, ca. $600 \mathrm{bp}$ free of introns) using the primer pair S1-SU19R (Fiore-Donno et al., 2008) (Table I). The amplification of the partial EF1a gene (ca $900 \mathrm{bp}$ ) was performed in one run for 5 specimens. The primers PB1FPB1R for these amplifications were designed by the third author (Table I). Sequencing was carried out at an ABI 3130 sequencer. All sequences reported as new in this paper have been deposited in GenBank under accession numbers KJ659863 to KJ659867 for SSU and KJ676601 to KJ676605 for EF1a.

Table 1 Primers used in this study.

\begin{tabular}{clc}
\hline Primer name & \multicolumn{1}{c}{ Sequence } & Melting temperature, ${ }^{\mathbf{0}} \mathbf{C}$ \\
\hline S1 & AACCTGGTTGATCCTGCC & 62 \\
SU19R & TCGAGTAACAATTAGAGGACA & 56 \\
PB1F & ACCCGTGAGCACGCTCTCCT & 60 \\
PB1R & CGCACATGGGCTTGGAGGGG & 60 \\
\hline
\end{tabular}

The obtained sequence chromatograms were first checked for reading errors in Chromas Lite (http://www.technelysium.com.au/chromas_lite.html) and aligned using MAFFT software version 6.935. From the resulting alignments with 631 nucleotide positions for the SSU gene and 249 amino acid positions for the EF1a gene we first constructed a Maximum Likelihood (ML) tree using the IQ-Tree software version 0.9.6 (http://www.cibiv.at/software/iqtree/). The partition model was used to create a phylogenetic tree based on both input alignments with independent model parameters estimation. The TNe+G4 model was selected for the SSU partition and the WAG+I model for the EF1a partition according to ModelTest implemented in IQ-Tree. 10000 ultrafast bootstrap replicates were performed for obtaining confidence values for the branches. For the Bayesian analysis, the MrBayes software was used (www.mrbayes.sourceforge.net/). The "mixed" data type was used for the two partitions, allowing independent estimation of model parameters. The GTR $+\mathrm{I}+\mathrm{G}$ model was used for both partitions. Two chains with 1000000 generations each were run; 10000 trees were sampled from each chain. All trees sampled before the convergence value of the two chains reached a value less that 0.01 were discarded as burn-in. The resulting 18940 trees were summarized to a consensus. Since the tree topologies from the Bayesian and ML analysis are identical, the bootstrap values from the ML analysis were drawn onto the Bayesian tree with the IQ-Tree software.

\section{Results}

Diderma cattiense Novozh. \& D.W. Mitch. sp. nov.

Fig. 1

MycoBank MB 808647

GenBank KJ659863 (18S SSU), KJ676601 (EF1a)

Holotype - LE 286673

Etymology - The specific epithet refers to the geographical location of the find and is derived from the name of the adjacent Cat Tien National Park.

Macromorphology - sporocarps grouped in small colonies (Figs. 1b, c), stipitate, 0.8-1.5 mm tall. Hypothallus cartilaginous to membranous, moderate reddish brown (m.rBr 43), pleated toward the stalk. Stalk $1 / 2-2 / 3$ of the total height, straight, moderate reddish brown (m.rBr 43) flared at the base (Fig. 1d), dark reddish brown (d.rBr 44) in the upper part, merging at the top into the discshaped sporangial brownish black (brBlack 65) base without brown lines (Fig. 1f). Sporotheca 0.5$1.0 \mathrm{~mm}$ diam., subglobose to subdiscoid with polyhedral dehiscence reticulum of light brown (l.Br 57) bands (Fig. 1d).

Micromorphology - peridium three-layered (Figs. 1h, j) composed of a smooth, glossy moderate reddish brown (m.rBr 43), cartilaginous outer layer with dark brown spots visible in transmitted light (Fig. 1i), middle white crystalline calcareous layer with lime globules and needles (Figs. 1j, k), and an inconspicuous, membranous inner layer (Fig. 1j). Dehiscence apical and 
floriform (Figs. 1e, f, g). Columella globose or subglobose (Fig. 1g), 0.15-0.25 mm diam., yellowish white (yWhite 92). Capillitium abundant, consisting of long, filiform threads c. $1 \mu \mathrm{m}$ diam., white under the dissecting microscope (Fig. 1g) and hyaline by transmitted light (Fig. $1 \mathrm{n}$ ), sparingly branching and rarely anastomosed (Fig. 1l), marked with scattered numerous small verrucae 0.5-1 $\mu \mathrm{m}$ high (Fig. 1m). Spores (brBlack 65) brownish black in mass, greyish reddish brown (gy.rBr 46) by transmitted light (Fig $1 \mathrm{n}$ ), globose, 10.5-11.5 $\mu \mathrm{m}$ in diam., unevenly covered by large blunt tuberous warts $0.4-0.6 \mu \mathrm{m}$ in height (Figs. 10, p). Plasmodium white.

Habitat - on strongly decayed coarse woody debris of unidentified trees (Fig. 1a), in a monsoon deciduous lowland tropical forest.

Known distribution - known only from a few sites in the Cat Tien National Park in Lam Dong Prov., southern Vietnam.

Material examined - Vietnam, Dong Nai Province, Tan Phu District, Cat Tien National Park, right bank of the Dong Nai River (upper reach), the south Vietnamese lowland dense monsoon semideciduous tropical secondary forest in depression with numerous coarse wood debris, $11^{\circ} 25^{\prime} 47.0^{\prime \prime} \mathrm{N} 107^{\circ} 25^{\prime} 23.2^{\prime \prime} \mathrm{E}, 165 \mathrm{~m}$ a.s.l., on large rotten log of an undetermined tree covered by mosses, 14th Nov 2011, Yu. Novozhilov (LE 286673 Holotype). The lowland dense monsoon

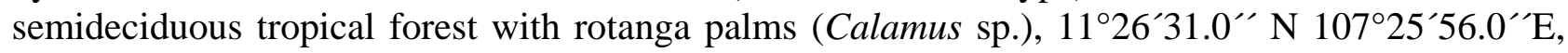
$140 \mathrm{~m}$ a.s.l., on rotten logs of unidentified trees covered by mosses, 30th Dec 2010, Yu. Novozhilov (LE 221710, 221722, 291355). Near road from the Heaven streams, the south Vietnamese lowland dense monsoon semideciduous tropical Dipterocarpus forest on well drained sandy soil, $11^{\circ} 26^{\prime} 39.0^{\prime \prime} \mathrm{N} 107^{\circ} 26^{\prime} 11.6^{\prime \prime} \mathrm{E}, 143 \mathrm{~m}$ a.s.l., on large log of an undetermined tree covered by mosses, 31th Dec 2010, Yu. Novozhilov (LE 221712). The secondary forest with

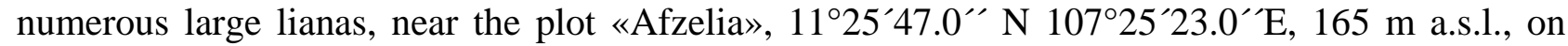
logs of unidentified trees covered by mosses, 23th Jan 2011, Yu. Novozhilov (LE 221712, 286697, 286700, 291287, 291292, 291293, 291340, 291341). The secondary forest in depression with numerous large lianas and coarse woody debris, $11^{\circ} 25^{\prime} 47.6^{\prime \prime} \mathrm{N} 107^{\circ} 25^{\prime} 31.8^{\prime \prime} \mathrm{E}, 173 \mathrm{~m}$ a.s.l., on logs of unidentified trees covered by mosses, 24th Jan 2011, Yu. Novozhilov (LE 221729). The lowland dense monsoon semi-decidous tropical forest with dominant trees of the second layer-

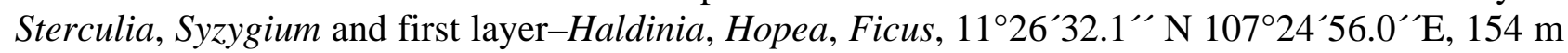
a.s.l., on rotten logs of unidentified trees covered by mosses, 17th Dec 2012, Yu. Novozhilov (LE 286704, 286705, 286707).

Agar cultures were prepared for a total of 5 isolates (field specimens). Spores germinated in all cultures 1-2 days after being sown on agar. Germination was through a V-shaped split in the spore wall. Significant amount of amoeboflagellates encysted almost immediately after germination; however, the population of myxamoebae grew rapidly, feeding on bacteria sown accidentally with spores and remains of sporocarps. After 5-10 days small hyaline microplasmodia looking like protoplasmodia appeared, ingesting microcysts and showing a slow irregular streaming of cytoplasm with many large vacuoles. Phaneroplasmodia were observed first 21-26 days after germination, and mature plasmodia were white and displayed feeding fronts up to $3 \mathrm{~cm}$ wide. In one isolate (LE 221729) phaneroplasmodia appeared only after 85 days. The addition of sterilized oat flakes appeared to be a crucial factor for growth of phaneroplasmodia. Agar cultures sporulated in 2 of 5 isolates after 7.5-8.5 months of cultivation.

The features of the species were constant among all studied field collections as well as specimens obtained in agar culture. Most microscopic characters were found to be stable. However, the columella of sporotheca and the spores obtained in agar cultures are often larger $(12.5-17.5 \mu \mathrm{m}$ in diam.). In contrast, the size and colour of sporothecae, as well as spore ornamentation were more stable.

Notes - D. cattiense belongs in the subgenus Leangium and appears closest to D. subasteroides M. L. Farr (1971) from which it differs in its peridium with polyhedral dehiscence reticulum of pale bands (Fig 1c, d), absence of distinct brown lines in dark brown basal discs of sporotheca (Fig. 1f), crystalline middle layer of capillitium with lime needles (Figs. 1j, k), smaller spores (Fig. 1n, 10.5-11.7 $\mu \mathrm{m}$ vs. 12-13 $\mu \mathrm{m}$ diam. in D. subasteroides), spore ornamentation 


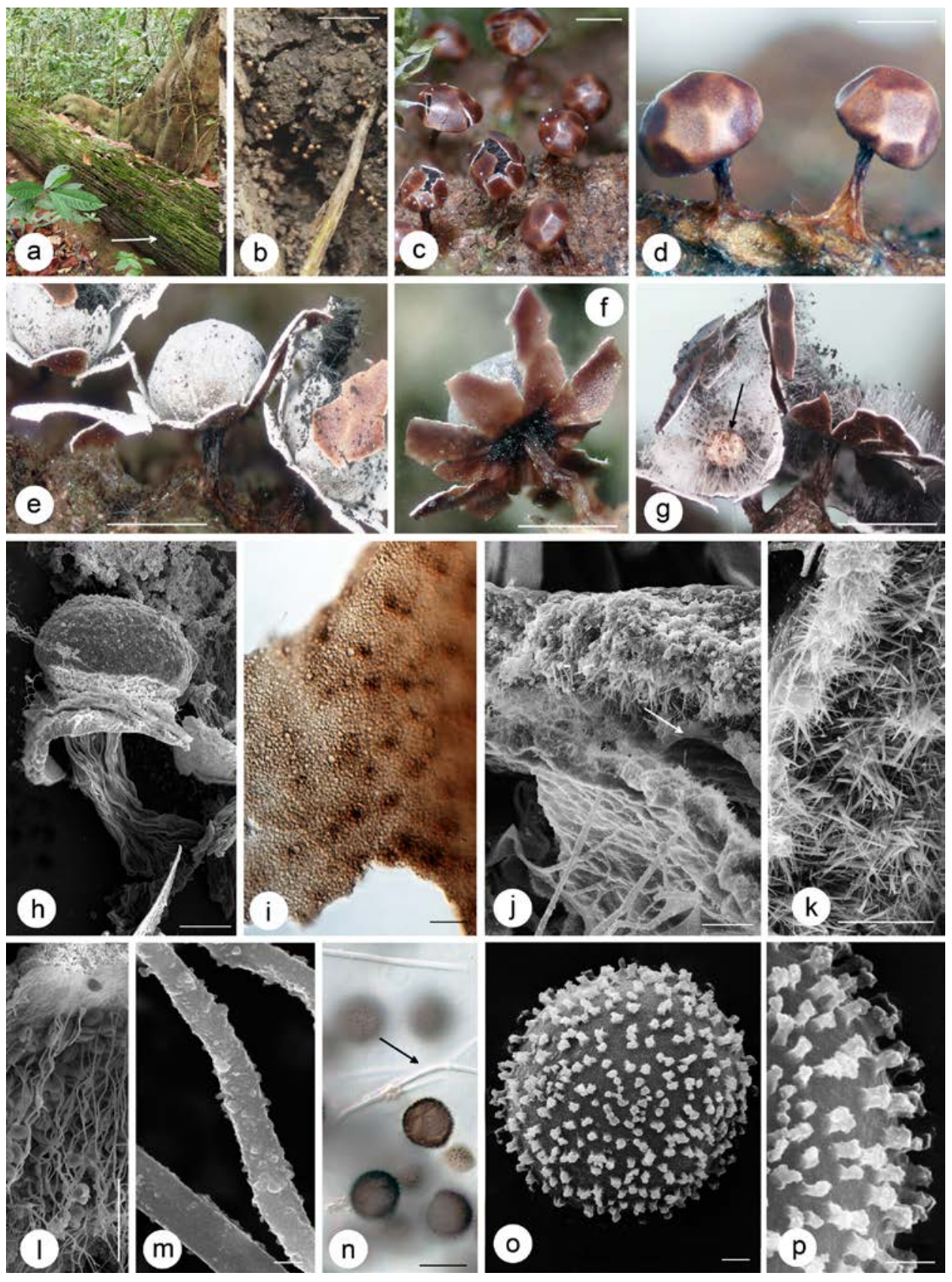

Figs 1 - Type locality and morphological characters of Diderma cattiense (LE ) a The large log with strongly decayed wood and dense moss cushion on upper side - typical habitat of Diderma cattiense (place where the type specimen LE 221444 was found marked by arrow), b Group of mature sporocarps on decayed wood in the field, c Group of mature sporocarps under the dissection microscope (DM, top view), d Two mature sporocarps with areolate peridium, (DM, side view), e Opened sporocarps with hyaline capillitium and white inner layer of peridium (DM, side view), $\mathbf{f}$ Opened sporocarp with the disc-shaped dark sporangial base (DM, bottom view), g Opened sporocarp with large globose light columella (shown by arrow) and hyaline capillitium (DM), h Scanning electron micrograph (SEM) of an opened sporocarp, i Portion of outer surface of peridium marked by dark spots as visible with light microscope with differential interference contrast (LM, DIC, $\times 100$ ), $\mathbf{j}$ SEM micrograph of three-layered peridium with needles of lime between outer and inner layers (middle layer of peridium shown by arrow), $\mathbf{k}$ SEM micrograph of middle layer of peridium with lime needles, I SEM micrograph of capillitium, $\mathbf{m}$ SEM micrograph of capillitium ornamentation, $\mathbf{n}$ Spores and hyaline capillitium (top and median view, LM, DIC, $\times 100$ ), o SEM micrograph of a spore, $\mathbf{p}$ Spore ornamentation $($ SEM). - Bars: $\mathrm{b}=1 \mathrm{~cm}$; $\mathrm{c}-\mathrm{g}, \mathrm{k}=$ $500 \mu \mathrm{m} ; \mathrm{h}=100 \mu \mathrm{m} ; \mathrm{l}=50 \mu \mathrm{m} ; \mathrm{i}-\mathrm{k}, \mathrm{n}=10 \mu \mathrm{m} ; \mathrm{m}, \mathrm{o}-\mathrm{p}=1 \mu \mathrm{m}$. 
(unevenly covered by large verrucae, 0.4-0.6 $\mu \mathrm{m}$ height, Figs. 1o, p), pale, hyaline, simple, nonreticulate, weakly dichotomous capillitium (Figs. 1g, l, m, n) vs. brown and reticulate in $D$. subasteroides, and prominent, well developed, globose or subglobose columella (Fig. 1g).

The new species differs in a number of important characters from other species (Table 1) with stalked sporocarps and three-layered (triple) peridium: D. asteroides (Lister \& G. Lister) G. Lister (Lister 1911), D. lohgadense S.D. Patil, R.L. Mishra \& Ranade (Mishra \& Ranade 1979), D. petaloides Buyck (Buyck 1983), D. stellulum M. L. Farr (Farr 1988), and D. yucatanense Estrada, Lado \& S. L Stephenson (Lado et al. 2003). The former can be distinguished from D. cattiense for its discoid pinkish or light brown sporothecae and pulvinate columella. Diderma lohgadense has saucer shaped or inverted bell-shaped sporotheca unlike subglobose sporotheca of $D$. cattiense. Diderma petaloides and $D$. stellulum have reticulate capillitium, the threads with numerous dark brown, expanded junctions and expansions, the former additionally has large spores (14-16 $\mu \mathrm{m})$, paler on one side and marked with spinules and blunt warts arranged in a subreticulate pattern. $D$. asteroides differs in its short-stipitate or sessile habit.

Table 2 Comparison of morphological characters of Diderma cattiense and six other similar species of Diderma.

\begin{tabular}{|c|c|c|c|c|c|c|c|}
\hline \multirow{2}{*}{ Characters } & \multicolumn{7}{|c|}{ Diderma } \\
\hline & DIDcat & DIDsub & DIDast & DIDloh & DIDpet & DIDste & DIDyuc \\
\hline $\begin{array}{l}\text { Total height } \\
\text { of sporocarp } \\
(\mathrm{mm})\end{array}$ & $0.8-1.5$ & $1.2-1.8$ & $0.5-1.0$ & 1.0-1.4 & $1.2-1.8$ & $2.5-3.0$ & $0.6-0.9$ \\
\hline $\begin{array}{l}\text { Sporotheca } \\
\text { diam. (mm) }\end{array}$ & 0.5-1.0 & $0.5-1.0$ & $0.5-1.0$ & $1.0-1.6$ & $0.8-1.0$ & $1.8-2.0$ & $0.4-1.0$ \\
\hline $\begin{array}{l}\text { Colour of } \\
\text { sporotheca }\end{array}$ & $\begin{array}{c}\text { glossy } \\
\text { moderate } \\
\text { reddish } \\
\text { brown with } \\
\text { polyhedral } \\
\text { dehiscence } \\
\text { reticulum of } \\
\text { light brown } \\
\text { bands }\end{array}$ & $\begin{array}{l}\text { evenly } \\
\text { coloured, } \\
\text { glossy } \\
\text { brown }\end{array}$ & $\begin{array}{l}\text { glossy, } \\
\text { dark red- } \\
\text { brown }\end{array}$ & $\begin{array}{l}\text { dark } \\
\text { chestnut } \\
\text { brown to } \\
\text { reddish } \\
\text { brown }\end{array}$ & $\begin{array}{c}\text { dark } \\
\text { greyish } \\
\text { brown with } \\
\text { polyhedral } \\
\text { pale } \\
\text { dehiscence } \\
\text { lines }\end{array}$ & brown & $\begin{array}{l}\text { yellowish } \\
\text { pink to } \\
\text { light } \\
\text { reddish } \\
\text { brown }\end{array}$ \\
\hline $\begin{array}{l}\text { Shape of } \\
\text { sporotheca }\end{array}$ & $\begin{array}{l}\text { subglobose } \\
\text { to } \\
\text { subdiscoid }\end{array}$ & $\begin{array}{l}\text { hemisphae } \\
\text { rical to } \\
\text { subdiscoid }\end{array}$ & $\begin{array}{c}\text { subglobose } \\
\text { or slightly } \\
\text { prolate }\end{array}$ & $\begin{array}{c}\text { saucer } \\
\text { shaped or } \\
\text { inverted } \\
\text { bell- } \\
\text { shaped }\end{array}$ & $\begin{array}{l}\text { subglobose } \\
\text { to } \\
\text { subdiscoid }\end{array}$ & subglobose & $\begin{array}{l}\text { hemisphe- } \\
\text { ric } \\
\text { depressed } \\
\text { to discoid, } \\
\text { slightly } \\
\text { umbilicate } \\
\text { above }\end{array}$ \\
\hline $\begin{array}{c}\text { Stalk size \% } \\
\text { of the total } \\
\text { height }\end{array}$ & $50-60$ & $60-70$ & 0-10 & 75-80 & $50-60$ & $50-60$ & $50-60$ \\
\hline $\begin{array}{l}\text { Middle layer } \\
\text { of peridium }\end{array}$ & $\begin{array}{l}\text { white, } \\
\text { calcareous, } \\
\text { crystalline } \\
\text { with lime } \\
\text { needles }\end{array}$ & $\begin{array}{l}\text { white } \\
\text { noncrystal } \\
\text { line, } \\
\text { calcareous } \\
\text { without } \\
\text { lime } \\
\text { needles }\end{array}$ & $\begin{array}{l}\text { white and } \\
\text { calcareous }\end{array}$ & $\begin{array}{l}\text { white and } \\
\text { calcareous }\end{array}$ & $\begin{array}{l}\text { white and } \\
\text { calcareous }\end{array}$ & $\begin{array}{l}\text { white and } \\
\text { calcareous }\end{array}$ & $\begin{array}{c}\text { white, } \\
\text { calcareous }\end{array}$ \\
\hline $\begin{array}{l}\text { Shape of } \\
\text { columella }\end{array}$ & $\begin{array}{l}\text { globose or } \\
\text { subglobose }\end{array}$ & flat & $\begin{array}{l}\text { hemispheri } \\
\text { cal or } \\
\text { conical }\end{array}$ & $\begin{array}{l}\text { thickened } \\
\text { base of } \\
\text { sporotheca }\end{array}$ & $\begin{array}{c}\text { hemispheri- } \\
\text { cal or } \\
\text { clavate }\end{array}$ & $\begin{array}{c}\text { flat or } \\
\text { thickened } \\
\text { base of } \\
\text { sporotheca }\end{array}$ & pulvinate \\
\hline
\end{tabular}




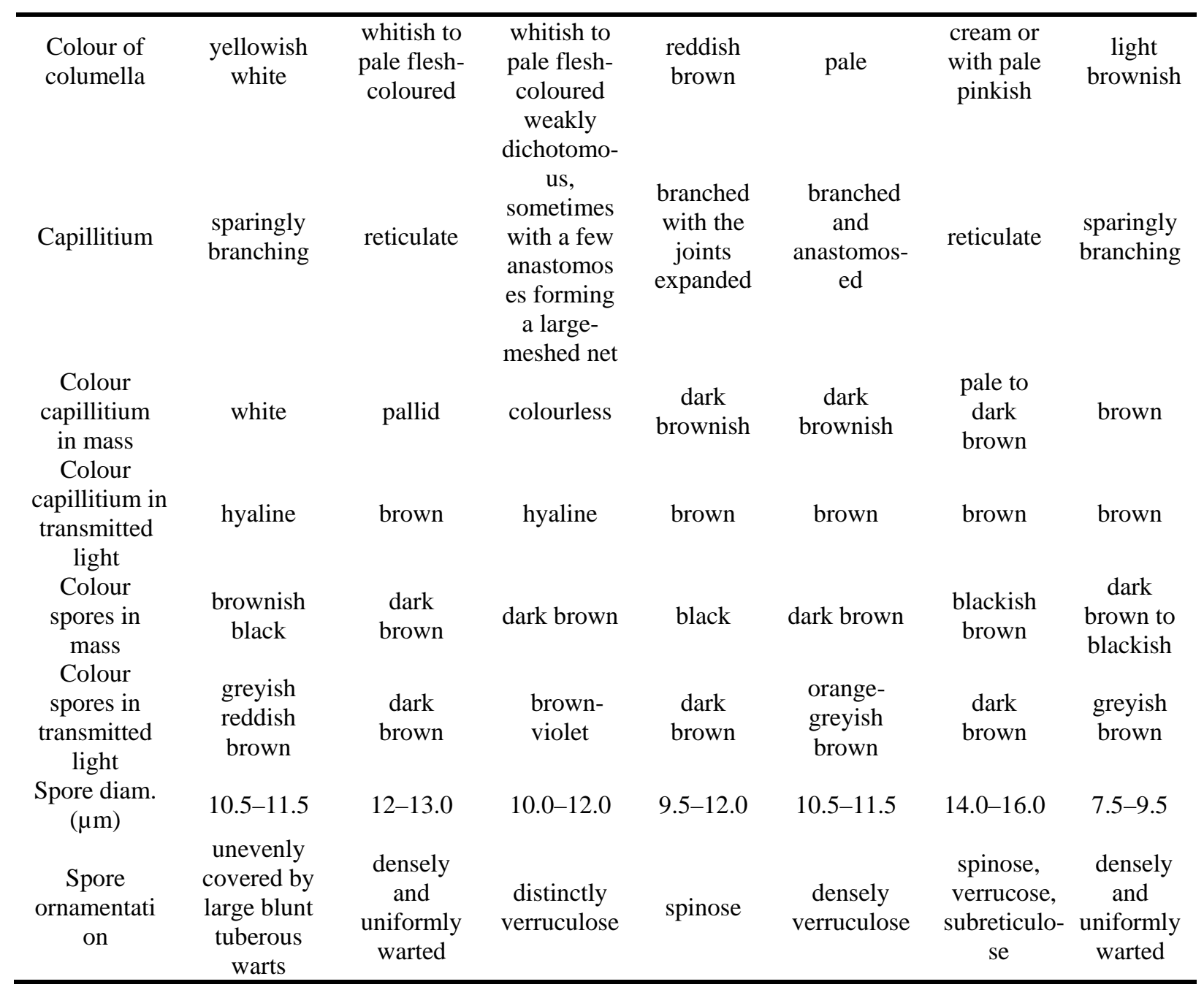

Abbreviations: DIDcat - Diderma cattiense, DIDsub - D. subasteroides, DIDast - D. asteroides, DIDloh - D. lohgadense, DIDpet - D. petaloides, DIDste - D. stellulum, DIDyuc - D. yucatenense.

Diderma pseudotestaceum Novozh. \& D.W. Mitch. sp. nov.

Fig. 2

MycoBank MB 808648

\section{GenBank KJ659866 (18S SSU), KJ676604 (EF1a)}

Holotype - LE 291396

Etymology - From the Latin pseudo (seeming), referring to the similarity of this species to Diderma testaceum.

Macromorphology - sporocarps in small groups, sessile, flat-pulvinate, rounded, slightly umbilicate above, 0.3-0.7 mm diam., white (White 263) but never pinkish. Hypotallus distinct, white, calcareous or thin, delicate, colourless.

Micromorphology - peridium double, outer layer white smooth, polished, porcelain-like with white inner surface, fragile, consisting of lime globules 1.5-2.5 $\mu \mathrm{m}$ diam., inner layer membranous bluish white (bWhite 189) under the dissection microscope. Dehiscence apical and frequently breaking to leave a ridge. Columella indefinite as a thickened light yellowish pink (l.yPk 28) or light orange (1.O 52) base of sporocarp. Capillitium abundant, consisting of filiform threads c. 0.5 $\mu \mathrm{m}$ diam., white under the dissecting microscope and hyaline by transmitted light, sparingly branching with membranous expansions. Spores dark grey (d.Gy 266) or black (Black 267) in mass, pale yellowish pink (p.yPk 31) or brownish pink (brPk 33) by transmitted light, globose, 6.2$7.2 \mu \mathrm{m}$ in diam., verruculose, unevenly covered by warts, some of the warts in clusters. Plasmodium unknown. 
Habitat - on ground litter and litter accumulated on large logs of trees, in a monsoon deciduous lowland tropical forest.

Known distribution - known only from a few sites in the Cat Tien National Park in Lam Dong Prov., southern Vietnam.

Material examined - Vietnam, Dong Nai Province, Tan Phu District, Cat Tien National Park, right bank of the Dong Nai River (upper reach), trail to the tree of Uncle Dong, the south Vietnamese lowland dense monsoon semideciduous tropical forest with Lagerstroemia calyculata

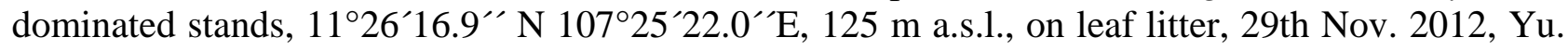
Novozhilov (LE 291396 Holotype). The south Vietnamese lowland dense monsoon semideciduous tropical forest with Lagerstroemia calyculata dominated stands $11^{\circ} 26^{\prime} 38.9^{\prime \prime} \mathrm{N} 107^{\circ} 23^{\prime} 49.0^{\prime \prime} \mathrm{E}, 166$ $m$ a.s.l., on ground litter, 20th Nov 212, Yu. Novozhilov (LE 291320). The dense monsoon semidecidous secondary tropical forest with numerous large lianas with Afzelia xylocarpa and Ficus sp.

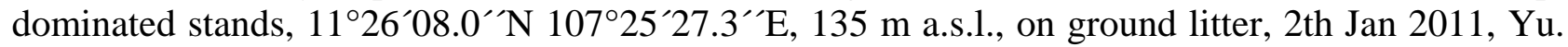
Novozhilov, in moist chamber cultures (LE 297164, 297165, 297486), field collections (LE 291397, 291398, 291399, 291400). The dense monsoon semi-decidous secondary tropical forest with numerous large lianes with Afzelia xylocarpa and Ficus sp. dominated stands, $11^{\circ} 26^{\prime} 15.5^{\prime \prime} \mathrm{N}$ $107^{\circ} 25^{\prime} 18.9^{\prime \prime}$ E, $152 \mathrm{~m}$ a.s.l., on ground litter, 16th Nov 2011, Yu. Novozhilov, field collections (LE 286716, 286718, 286751). The secondary dense forest with numerous large lianas, Lagerstroemia calyculata, sagos and giantic aroids, $11^{\circ} 27^{\prime} 05.4^{\prime \prime} \mathrm{N} 107^{\circ} 21^{\prime} 24.9^{\prime \prime} \mathrm{E}, 162 \mathrm{~m}$ a.s.l., on ground litter, 27th Jan 2011, Yu. Novozhilov, in moist chamber culture (LE 297199).

Notes - The twelve collections studied were found in six localities at different times, on ground litter and litter that accumulated on the surface of large logs of trees. In each case, the fructifications were very scanty, consisting of small groups (10-30) of sporocarps. The features of the species were constant among all studied field collections as well as specimens obtained in moist chamber cultures. Most microscopic characters were found to be stable. However, the capillitium of sporocarps obtained in moist chamber cultures were often scanty. In contrast, the shape and size of sporothecae and spores, shape and colour of columella, as well as spore ornamentation, were more stable.

Some sporocarps were used in attempts to establish spore to spore agar cultures (Haskins \& Wrigley de Basanta 2008). However, these attempts failed and observations of spores in hanging drops showed that they did not germinate within three days.

Macroscopically, this species slightly looks like D. testaceum. However we assume that pinkish colour of sporocarps (Figs. 2j, k) as well as prominent, convex reddish brown columella (Fig. 2k) are typical characteristics of Diderma testaceum «sensu stricto». Diderma pseudotestaceum is best distinguished from this species by the clear white colour of the peridium, flat-pulvinate and umbilicate above the sporotheca and absence of a prominent columella. Interestingly, a similar morphotype was described from Taiwan (Chung and Liu 1998). These authors noted that their specimens differed from the typical form of $D$. testaceum in having a white inner surface of outer peridium and undeveloped columellae, nevertheless they retain this form as D. testaceum.

Molecular analysis - For the comparison of molecular characteristics of the two new Diderma species, we obtained 5 partial 18S ribosomal DNA (SSU) as well as 5 partial elongation factor alpha (EF1a) sequences.

A BLAST search (http://blast.ncbi.nlm.nih.gov/Blast.cgi) revealed that the closest sequenced Diderma species to $D$. cattiense are D. niveum (according to the $18 \mathrm{~S}$ SSU gene) and $D$. globosum var. europaeum (according to the EF1a gene). The closest species to D. pseudotestaceum was $D$. alpinum. The mentioned taxa were then used in a two-gene phylogenetic analysis including two samples of $D$. cattiense and 3 samples of $D$. pseudotestaceum.

The analyzed taxa, D. cattiense and D. pseudotestaceum, each form a separate monophyletic clade on the phylogenetic tree with maximal Bayesian and bootstrap support values, thus supporting the species status of these taxa (Fig. 3). The GenBank accession numbers for third-party sequences used in this analysis are given in the Table 3. Since morphologically D. pseudotestaceum 

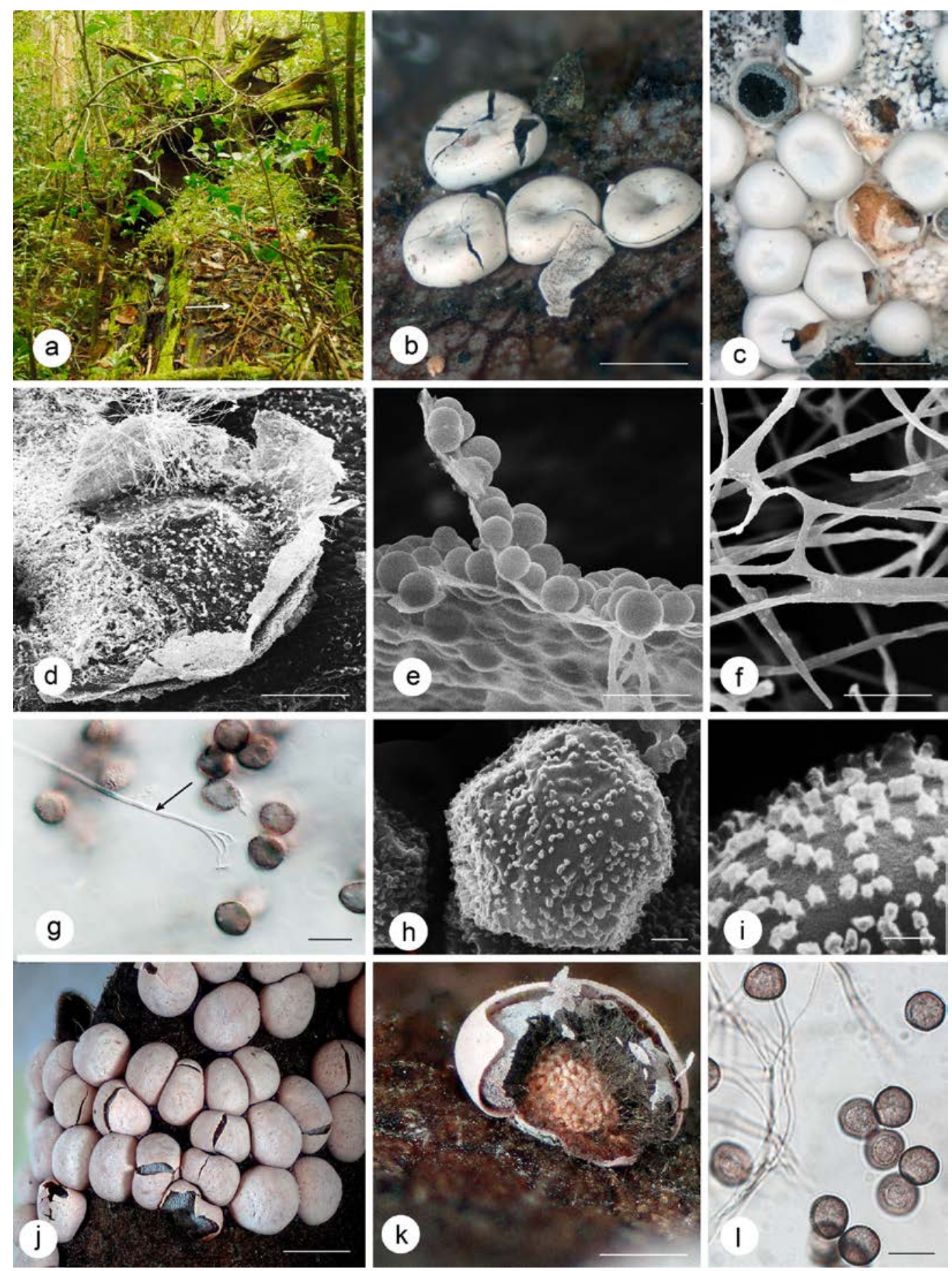

Figs 2 - Type locality and morphological characters of Diderma pseudotestaceum (LE 291396) and morphological characters of $D$. testaceum (LE 297668) a The large log with strongly decayed wood covered by leaf litter on upper side - typical habitat of $D$. pseudotestaceum (place where the type specimen LE 291396 was collected marked by arrow), b Group of mature sporocarps on leaf litter in the field (side view), c Group of mature sporocarps with reddish bottom under the dissection microscope (DM, top view), d Scanning electron micrograph (SEM) of an opened sporocarp, e SEM micrograph of a portion of outer surface covered by lime granules, $\mathbf{f}$ SEM micrograph of capillitium, g Spores and hyaline capillitium as visible with light microscope with differential interference contrast (top and median view, LM, DIC, ×100), h SEM micrograph of a spore, $\mathbf{i}$ Spore ornamentation (SEM), $\mathbf{j}$ Group of mature sporocarps of $D$. testaceum with pinkish peridium (DM), k An opened sporocarp of $D$. testaceum with large reddish columella (DM), l Spores and hyaline capillitium of $D$. testaceum (median view, LM, DIC, $\times 100$ ). - Bars: b, c, k $=500 \mu \mathrm{m} ; \mathrm{d}=$ $100 \mu \mathrm{m}$; e, $\mathrm{f}=5 \mu \mathrm{m} ; \mathrm{g}, \mathrm{l}=10 \mu \mathrm{m} ; \mathrm{h}=1 \mu \mathrm{m} ; \mathrm{i}=0.5 \mu \mathrm{m} ; \mathrm{j}=1000 \mu \mathrm{m}$. 
is similar to D. testaceum, 18S SSU sequence of the latter species (GenBank accession number AB259385, Kamono \& Fukui 2006) was involved in the molecular analysis. This is the only trustworthy $18 \mathrm{~S}$ SSU sequence of $D$. testaceum available in the GenBank database. However, this sequence shows a fair amount of genetic divergence which hampers a proper alignment and tree reconstruction. Thus, this sequence was excluded from further analysis.

The results of molecular analysis support the recognition of two new morphospecies, Diderma cattiense (a liginicolous species) and D. pseudotestaceum (a litter inhabitant) both of which are seemingly common in lowland monsoon tropical forests of the Cat Tien National Park.

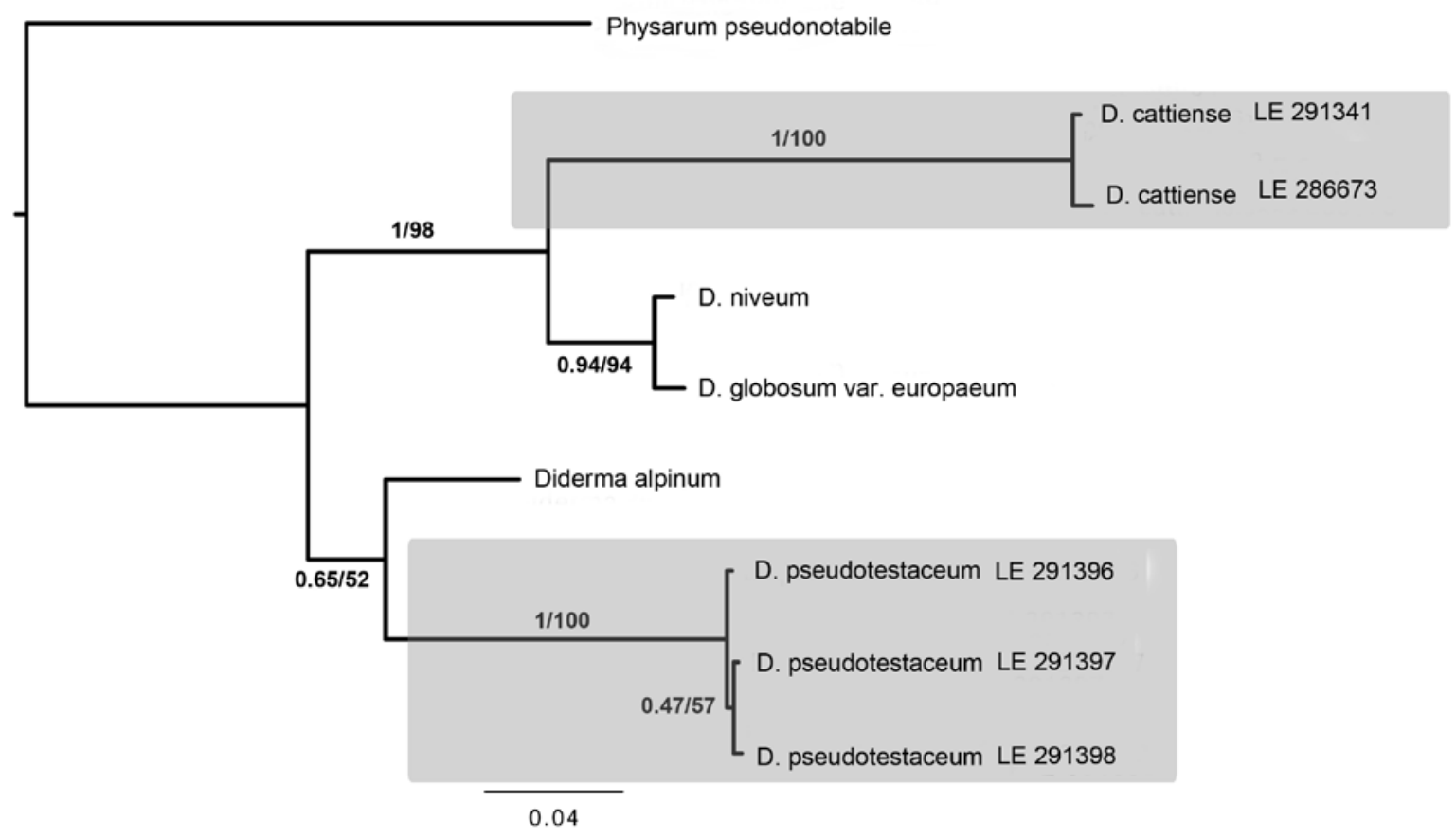

Fig. 3 - Phylogenetic tree based on the partial 18S SSU gene sequence (629 bp) and the partial EF1a gene sequence (246 a/a) of 9 taxa. Support values of Bayesian posterior probability (0-1) and ultra-fast bootstrap support (0-100) are given for each node. Clusters representing $D$. cattiense and D. pseudotestaceum are shaded grey. Physarum pseudonotabile (Novozhilov et al. 2013) was used as the outgroup. Scale bar indicates 0.04 substitutions per site.

Table 3 List of GenBank accession numbers of third-party sequences used in the phylogenetic analysis.

\begin{tabular}{lcc}
\hline Species & 18S SSU & EF1a \\
\hline D. niveum & HE614616 & GU289200 \\
D. globosum var. europaeum & DQ903677 & EF513191 \\
D. alpinum & JQ900778 & GU289199 \\
\hline
\end{tabular}

\section{Acknowledgments}

We gratefully acknowledge the technical support (SEM) provided by Ludmila A. Kartzeva, St. Petersburg (Komarov Botanical Institute RAS). The authors are grateful to the administration of the Joint Russian Vietnamese Tropical Research and Technological Centre and Cat Tien National Park and to A. N. Kuznetzov and A. E. Anichkin for their assistance in the organization of fieldwork. Expeditions and laboratory work were supported by the Russian Found for Basic Research (grant 13-04-00839-a, 12-04-33018 mol-a-ved) and the program Ecolan-1.2 of the Russian-Vietnamese Tropical Scientific and Technological Centre. 


\section{References}

Anichkin AE. 2011 - Dynamics of plant litter decomposition. Structure and functions of soil communities of a monsoon tropical forest (Cat Tien National Park, southern Vietnam). KMK Scientific Press, Moscow 44-75 [in Russian].

Anonymous. 2012 - NBS/ISCC Colour System. Original and Improved 267 Colour Centroids. Washington, Inter-Society Colour Council. National Bureau of Standards. http://tx4.us/nbsiscc.htm (Consulted 20 April 2014).

Blanc L, Maury-Lechon G, Pascal J.-P. 2000 - Structure, floristic composition and natural regeneration in the forests of Cat Tien National Park, Vietnam: an analysis of the successional trends. Journal of Biogeography 27, 141-157.

Buyck B. 1983 - Diderma petaloides Buyck, a new Myxomycete from Rwanda. Bulletin du Jardin Botanique National de Belgique 53(1-2), 294.

Chung CH, Liu CH. 1998 - Myxomycetes of Taiwan IX. The genus Diderma (Physarales). Taiwania 43(1), 12-26.

Farr ML. 1971 - Two undescribed Myxomycetes from Argentina. Mycologia 63 (3), 634-639.

Farr ML. 1988 - Notes on Mycetozoa V. Corrections, redispositions, and new taxa. International journal of mycologie and lichenology 3, 199-213.

Fiore-Donno AM, Meyer M, Baldauf SL, Pawlowski J. 2008 - Evolution of dark-spored Myxomycetes (slime-molds): molecules versus morphology. Mol. Phylogenet. Evol. 46 (3), 878-889.

Haskins EF, Wrigley de Basanta D. 2008 - Methods of agar culture of myxomycetes: an overview. Revista Mexicana de Micología 27, 1-7.

Kamono A, Fukui M. 2006 - Rapid PCR-based method for detection and differentiation of Didymiaceae and Physaraceae (myxomycetes) in environmental samples. J. Microbiol. Methods 67(3), 496-506.

Kuznetsov AN, Kuznetsova SP.2011 - Forest vegetation: species composition and stand structure. Structure and functions of soil communities of a monsoon tropical forest (Cat Tien National Park, southern Vietnam). KMK Scientific Press, Moscow 16-43 [in Russian].

Kuznetsov AN, Kuznetsova SP. 2013 - Tropical Monsoon Forests of Vietnam (Results of 20 Years of Phytoecological Research). Biology Bulletin 40(2), 187-196.

Lado C, Estrada-Torres A, Stephenson SL, Wrigley de Basanta D, Schnittler M. 2003 -Biodiversity assessment of myxomycetes from two tropical forest reserves in Mexico. Fungal Diversity 12, 67-110.

Lister G. 1911 - A monograph of the Mycetozoa; a descriptive catalogue of the species in the Herbarium of the British Museum. London, British Museum.

Mishra RL., Ranade VD. 1979 - Myxomycetes of Maharashtra-II. The genus Diderma Pers. Maharashtra Vidnyan Mandir Patrika 14(1), 33-41.

Novozhilov YK, Okun MV, Erastova DA, Shchepin ON, Zemlyanskaya IV, García-Carvajal E, Schnittler M. 2013 - Description, culture and phylogenetic position of a new xerotolerant species of Physarum. Mycologia 105: 1535-1546.

Singer H, Moreno G, Illana C. 2005 - Revision of type material of nivicolous species of Stemonitales. Persoonia 18(4), 485-497.

Thinh NV, Anichkin AE. 2011 - The Cat Tien National Park: general information. Structure and functions of soil communities of a monsoon tropical forest (Cat Tien National Park, southern Vietnam). KMK Scientific Press, Moscow 11-16 [in Russian]. 